\title{
Immunity to the Dual Threat of Silica Exposure and Mycobacterium tuberculosis
}

\begin{abstract}
Petr Konečný ${ }^{1,2 *}$, Rodney Ehrlich ${ }^{1}$, Mary Gulumian ${ }^{3,4,5}$ and Muazzam Jacobs ${ }^{2,5,6}$
${ }^{1}$ Centre for Environmental and Occupational Health, School of Public Health and Family Medicine, University of Cape Town, Cape Town, South Africa, ${ }^{2}$ Division of Immunology, Department of Pathology and Institute of Infectious Disease and Molecular Medicine, Faculty of Health Sciences, University of Cape Town, Cape Town, South Africa, ${ }^{3}$ National Health Laboratory Service, Department of Toxicology and Biochemistry, National Institute for Occupational Health, Johannesburg, South Africa, ${ }^{4}$ Division of Molecular Medicine and Haematology, University of the Witwatersrand, Johannesburg, South Africa, ${ }^{5}$ National Health Laboratory Service, Johannesburg, South Africa, ${ }^{6}$ Immunology of Infectious Disease Research Unit, South African Medical Research Council, Cape Town, South Africa
\end{abstract}

Exposure to silica and the consequent development of silicosis are well-known health problems in countries with mining and other dust producing industries. Apart from its direct fibrotic effect on lung tissue, chronic and immunomodulatory character of silica causes susceptibility to tuberculosis (TB) leading to a significantly higher TB incidence in silica-exposed populations. The presence of silica particles in the lung and silicosis may facilitate initiation of tuberculous infection and progression to active $\mathrm{TB}$, and exacerbate the course and outcome of TB, including prognosis and survival. However, the exact mechanisms of the involvement of silica in the pathological processes during mycobacterial infection are not yet fully understood. In this review, we focus on the host's immunological response to both silica and Mycobacterium tuberculosis, on agents of innate and adaptive immunity, and particularly on silica-induced immunological modifications in co-exposure that influence disease pathogenesis. We review what is known about the impact of silica and Mycobacterium tuberculosis or their co-exposure on the host's immune system, especially an impact that goes beyond an exclusive focus on macrophages as the first line of the defense. In both silicosis and TB, acquired immunity plays a major role in the restriction and/or elimination of pathogenic agents. Further research is needed to determine the effects of silica in adaptive immunity and in the pathogenesis of TB.

Keywords: tuberculosis, silica, immunity, macrophages, granulomas, $\mathrm{T}$ cell

\section{INTRODUCTION}

It has long been hypothesized that inhaled silica dust contributes to $\mathrm{TB}$ development and progression via its physicochemical and biological properties (1-3). However, while recent research has explored the role of silica in immune response impairment, the mechanisms of reaction to the combination of silica particles and Mycobacterium tuberculosis (Mtb) are poorly understood (4). In this review, the immunological responses to silica exposure and to Mtb are reviewed, either as independent pathways, or where evidence is available, in the context of co-exposure and dual disease. 


\section{Silica and Silicosis}

There are a number of pathologies associated with exposure to silica, including silicosis, lung malignancy, autoimmune disease and pulmonary infection, notably tuberculosis $(5,6)$.

Silicosis is a disease of the lower respiratory system caused by high dose and/or long-term inhalation of silica particles in mining and occupations involved in rock or sand processing, manufacturing of stone based products and utilization of sand as an abrasive agent (7-9). Silicosis results from the deposition of respirable silica particles in the lower respiratory tract, causing inflammation, collagen deposition, and fibrotic lesions. The outcome may vary from subclinical pathological changes to severe damage of lung tissue, diminished quality of life, and decreased lifespan (10). The development of a specific type of fibrotic granuloma the signal pathological lesion of silicosis is not restricted to the lungs but has also been observed in the liver, spleen, and bone marrow (11).

The prevalence of acute and severe silicosis due to very high exposures has decreased in the modern era and silicosis in general is uncommon in developed countries. However, silicosis remains prevalent in countries with extensive mining industries, such as China $(6,12,13)$, South Africa $(14,15)$, Mexico (16), Brazil (17), and India (18), and continues to be recorded in the USA (19) and Australia (20). However, many countries do not register occupational diseases accurately and the enduring "residence time" of silica in the lungs after exposure, with a long asymptomatic phase, prevents early diagnosis (21).

The immune system response to silica particles has been extensively studied. Research has focused mainly on the initial interaction with cells residing in the lungs and the immunological modification of innate immune cellular responses. Special attention has been paid to the first encounters of silica with alveolar macrophages (AMs). In general, silica particles enter the alveolar space after inhalation and interact with macrophages, resulting in the engulfment of inhaled particles into the phagosome. The MARCO scavenger receptor has been described as the main molecule responsible for silica recognition and uptake (22), although other receptors from the group of Pattern Recognition receptors (PRRs) can be involved. It has been shown that CD204 may also interact with silica and inhibit the activity of macrophages. Some of the PRRs, such as Tolllike receptors (TLRs), are crucial in the response to bacterial infection. Significant downregulation of Toll-like receptor 2 (TLR2) following silica exposure might be one of the reasons contributing to higher TB susceptibility (23). Finally, the inability of macrophages to digest and eliminate phagocytized particles leads to persistent inflammation and modification of cellular responses (24).

The toxicity and pathogenicity profile of silica and thus the risk of silicosis vary with the size, physical and chemical properties of the inhaled particles $(1,25)$. A number of studies have focused on identification and characterization of specific toxic parameters (25-33). For example, different admixtures in dust can alter the biological activity of the silica particles (1, 34-38). While crystalline structure has long been accepted as conferring toxicity on silica $(39,40)$, recent research suggests that the number and distribution of silanol and siloxane groups rather than crystallinity feature as the primary toxic factors (41).

\section{Silica and Tuberculosis}

Tuberculosis remains one of the most dangerous diseases of the modern world, causing more than 1.3 million deaths, and with over 10 million new (incident) TB cases worldwide, in 2017 (42). Many risk co-factors for TB have been identified, including malnutrition, alcohol, diabetes and drug abuse (43-46). HIV infection is a potent co-factor $(42,47)$, while a higher incidence of TB has also been observed in individuals suffering from parasitic infections such as malaria (48) and leishmaniasis (49). Inhalant co-factors include smoking (50) and indoor air pollution $(51,52)$. The co-occurrence of silica exposure, silicosis, and TB has long been identified in populations exposed to silica-containing dust $(53,54)$ and progression of TB associated with silica exposure or silicosis has been of interest at least since the beginning of twentieth century (55). The spectrum of effect after exposure to the two agents is complex. It ranges from retained silica particles in the lung and TB infection without active disease, to dual disease, referred to as silicotuberculosis. The fibrotic phase of silicosis may be sub-radiological and thus not clinically evident (56), while significant host pathological changes may be observed in the pre-fibrotic stages as a result of silica particle activity (57).

The protection of silica-exposed and silicotic individuals against mycobacterial infection and $\mathrm{TB}$ in particular remains an important clinical and public health issue in the twentyfirst century (58). Silica dust control, treatment of latent TB infection, early detection and effective treatment of $\mathrm{TB}$ are the main modalities of control. However, at the community level, a recent trial of mass treatment of latent $\mathrm{TB}$ infection in gold miners failed to show a reduction in $\mathrm{TB}$ incidence rates after treatment courses had ended (59). With respect to vaccination, the evidence does not support the use of Bacillus CalmetteGuérin (BCG) in tuberculin negative silica exposed workers or silicotics (60). For example, vaccination with BCG in guinea pigs exposed to silica-containing dust has been reported as causing an increase in fatal BCG infection, while an increased death rate from silicosis and silicotuberculosis has been observed in BCG vaccinated Bulgarian miners (61).

With the objective of understanding exposure-response effects, the risk as well as the progression and severity of mycobacterial infection in the presence of silica exposure have been investigated, using variable dust composition and concentrations of quartz (the most common crystalline silica polymorph), and various inoculation sites of different mycobacterial strains. While tracheal and, in particular, intravenous infection produce extensive pulmonary lesions, a subcutaneous introduction of bacilli did not show any pathological changes. It has also been confirmed that quartz represents the most toxic form and that there is a relationship between increasing dust/silica concentration, number of bacilli and development of tuberculous lesions (62). Co-exposure in vivo in guinea pig models has also provided information about the active role of $\mathrm{Mtb}$ in pneumoconio-tuberculous lesion formation, with the introduction of the antituberculotic drug 
rifampicin resulting in decreased formation or its elimination (63).

However, since activation of the immune system underlies disease activation and its accelerated progression, the factors targeting components of protective immune mechanisms and leading to impairment of defense against mycobacterial infections need to be understood. Exposure to silica decreases cellular function, reduces the capacity of dendritic cell activation and leads to a non-specific, impaired inflammatory response which compromises antibacterial mechanisms (64). These effects provide pathways for the promotion by silica exposure of increased susceptibility to bacterial infections, particularly Mycobacterium tuberculosis and other mycobacterial species $(63,65,66)$.

Detailed mechanisms leading to disease in the presence of silica and $\mathrm{Mtb}$ are not yet understood, and multiple pathways are likely to be involved. For example, genetic polymorphism of tumor necrosis factor alpha (TNF- $\alpha)$, natural resistanceassociated macrophage protein 1 (NRAMP1), and inducible nitric oxide synthase (iNOS) in macrophages have been shown to influence the response to both silica exposure or silicosis and $\mathrm{TB}$ in Chinese iron miners (67). Similar observations have been made in silicotic South African gold miners (68). Based on their specific single nucleotide polymorphism, different genotypes of the above-mentioned proteins showed intricate differential effects. These were either protective (variation of iNOS Ser608Leu genotype in silicosis) or had deleterious effects ( $\mathrm{G}>\mathrm{C}$ mutation of NRAMP1 intron 4 in silicosis, combined NRAMP1 D543N G/G and INT4 G/C+C/C, polymorphic site of G/A substitutions at positions-308 of TNF- $\alpha$ and TNF-a-308 G/G and NRAMP1 INT4 G/C+C/C genotype in TB) $(67,68)$.

Polymorphism of other genes related to the response to $\mathrm{TB}$ and silica such as transforming growth factor-beta 1 (TGF$\beta 1$ ) and cytokines interleukin 10 (IL-10) and interferon gamma (IFN $\gamma$ ) have been investigated, but no association found (69).

The following sections review the innate and adaptive cellular immune responses to silica and Mtb separately and with coexposure, according to the immune cells or processes involved. The findings are summarized in Table 1, which also highlights the gaps in knowledge.

\section{INNATE CELLULAR IMMUNE RESPONSES IN SILICOSIS AND TUBERCULOSIS}

\section{Alveolar Macrophages (AMs)}

Alveolar macrophages represent the first line of defense against many airborne pathogens and inhaled environmental particles. The reaction of AMs after exposure to silica $(70,105-115)$ has been extensively studied. The tissue remodeling and formation of granulomas in response to exposure to both silica and Mtb suggest that similar mechanisms are involved in the elimination process in individuals exposed to silica or Mtb separately (116-118). Results from several studies have confirmed a noticeable difference in growth of Mtb in macrophages preloaded with silica particles; macrophages were more susceptible to infection represented by an increase in the number of infected macrophages and a higher number of bacilli present in each cell (119). Thus, silica particles facilitate intracellular replication and subsequent release from macrophages (61).

Using BCG vaccine inoculations, silicotic mice exhibited a higher accumulation of BCG colonies in harvested organs linearly correlating with the length of incubation than naïve counterparts. After 12 weeks, more than 40 times more colonies were observed in the spleen of silicotic mice, 70 times more in the liver and more than 6,000 times more in the lungs. Presence of silica particles significantly affects cellular response and bacterial growth properties (71). Higher Mtb burdens have been observed in murine lungs preloaded with silica compared to silica-free control animals (73). Also, extracted AMs contained more engulfed bacilli. The transplantation of AMs from silica-exposed into control, silica-unexposed mice, resulted in an increase of susceptibility to TB upon infection with Mtb. Thus, macrophages preloaded with silica particles exhibit a higher number of Mtbphagocyting cells as well as higher rates of Mtb phagocytosis, leading to an increase in the number of bacteria engulfed in the macrophage (120). Silica-containing macrophages also display impaired capability to adhere and migrate compared to healthy controls (72).

Enhanced Mtb phagocytosis could be caused by an interaction with intracellularly located surfactant-associated protein A (SPA) or its related proteins (121-123) A significantly higher release of SP-A has been shown to follow exposure to silica (124) and this increase was associated with reduced silica-related toxicity to AMs $(62,125)$ analyzed the impact of various types of dust particles on lung tissue after co-administration with inoculated BCG and specifically on the development of fibrotic lesions. They demonstrated that rats and guinea-pigs developed only mild fibrotic lesions after exposure to mine dust, anthracite, kaolin, and BCG alone but large destructive lesions with combined dust and BCG.

\section{Dendritic Cells (DCs)}

The influence of silica exposure on DCs function has been little investigated. Beamer and Holian (126) describe an increase of DCs accompanying the decrease in numbers of AMs after exposure to silica. It has been reported that viability of DCs is compromised after exposure to silica particles (74). The role of DCs in resistance is also not well-documented in cases of silica potentiated TB. It has been shown that mycobacteria are able to enter the intracellular spaces of DCs via the specific surface protein DC-specific intercellular adhesion molecule-3 grabbing non-integrin (DC-SIGN) (127). Although the main carriers of $\mathrm{Mtb}$ are macrophages, the most infected population of cells in lymph nodes are DCs. The evidence is that antigen presentation properties and migration of DCs play important roles in the establishment of long-term infection (75). They also increase their antigen-presenting properties after infection with mycobacteria, facilitate immune system responses through secretion of pro-inflammatory cytokines [tumor necrosis factor alpha (TNF $\alpha)$, IL-1] and up-regulation of co-stimulatory (CD54, CD40) molecules (76). DCs also specifically stimulate the production of IFN $\gamma$ by $\mathrm{T}$ cells after exposure to Mtb (128). 
TABLE 1 | Basic summary of acquired knowledge about specific components of the immune system after exposure to silica, Mtb, or both, highlighting the gaps and opportunities for future research.

\begin{tabular}{|c|c|c|c|}
\hline & Silica & Mtb & Silica + Mtb \\
\hline Macrophages & $\begin{array}{l}\text { Dose-dependent Induction of } \\
\text { apoptosis, fibrotic nodule } \\
\text { formation, chronic activation of } \\
\text { inflammatory and } \\
\text { anti-inflammatory pathways, } \\
\text { ROS, and RNI production (6) }\end{array}$ & $\begin{array}{l}\text { Granuloma formation, chronic inflammation, survival } \\
\text { mechanisms: ROS and RNI detoxification, blockade of } \\
\text { phagosome maturation, granuloma formation (70) }\end{array}$ & $\begin{array}{l}\text { Increase in Mtb uptake (71); } \\
\text { impairment of adhesion and } \\
\text { migration }(72,73)\end{array}$ \\
\hline Dendritic cells & Lower viability (74) & $\begin{array}{l}\text { Cells with the highest bacterial burden in lymph nodes (75); } \\
\text { increase in antigen presentation and secretion of } \\
\text { pro-inflammatory cytokines (76); activation of adaptive } \\
\text { immunity ( } 77 \text { ) }\end{array}$ & Yet to be investigated \\
\hline Neutrophils & $\begin{array}{l}\text { Decreased phagocytosis and } \\
\text { viability }(78,79)\end{array}$ & $\begin{array}{l}\text { Control of Mtb replication, prolonged activation-tissue } \\
\text { damage (80); trapping of bacilli (81); facilitation of disease } \\
\text { progression (82) }\end{array}$ & Yet be investigated \\
\hline NKs & $\begin{array}{l}\text { Decrease in NKs }(83,84) \text {; silica } \\
\text { nanoparticles cause increase in } \\
\text { NKs (85) }\end{array}$ & Protective role of $\mathrm{NKs}$ - production of IFN $\gamma(86)$ & Yet to be investigated \\
\hline Antigens & $\begin{array}{l}\text { Inconsistent evidence, increase } \\
\text { in antigen-presenting properties } \\
\text { of AMs (87) }\end{array}$ & $\begin{array}{l}\text { CD1 mediated T cell activation }(88,89) \text {; signaling for APCs } \\
\text { (90) }\end{array}$ & Yet to be investigated \\
\hline T cells CD4+, CD8+, $\gamma \delta$ T cells & $\begin{array}{l}\text { Increase in FAS ligand-higher } \\
\text { rate of apoptosis (91); shift } \\
\text { between Th1/Th2 response } \\
\text { (92-96); Tregs and Tresps } \\
\text { activation ( } 97) \text {; reduced inhibitory } \\
\text { activity of T cells (98) }\end{array}$ & $\begin{array}{l}\text { Bacteriostatic and bactericidal effect }(77) ; \mathrm{IFN} \gamma \\
\text { production - phagocytic properties of macrophages, Th2 } \\
\text { response activation and Tregs production }(99,100)\end{array}$ & $\begin{array}{l}\text { Sporadic and contradictory } \\
\text { evidence }\end{array}$ \\
\hline Antibody-mediated immunity (B cells) & $\begin{array}{l}\text { Increase and decrease in B cell } \\
\text { activity (101); increase in } \\
\text { autoantibodies (97) }\end{array}$ & $\begin{array}{l}\text { B cells are the producers of antibodies, modulators of T cell } \\
\text { activity and T cell memory, influencing function of dendritic } \\
\text { cells (102); association with containment of Mtb (103); CD4+ } \\
\text { T cell regulation (104) }\end{array}$ & Yet to be investigated \\
\hline
\end{tabular}

\section{Neutrophils}

Neutrophils rapidly respond to pathogen challenge and contribute to control of Mtb replication. However, apart from its protective properties, the cell's prolonged oxidative and proteolytic activity also lead to tissue damage (80). Neutrophils possess the direct ability to restrict Mtb by engulfment of bacilli $(129,130)$. Increased influx of neutrophils into Mtb-infected tissue has been observed although in this study no bacteria were found inside these cells. This might point to antibacterial activity independent of phagocytosis (131). Their detailed role in disease is thus not yet fully understood.

It has been found that low concentrations of neutrophils in the peripheral blood cause incapability to restrict or kill introduced Mtb (132). Its oxidative phagocytic properties may kill some of the bacteria after phagocyting the dying macrophage (133). Antimicrobial extracellular traps (NETs) formed by neutrophils are also able to contribute to antimycobacterial activity by trapping bacilli, but not often by killing them (81). Neutrophilrelated restriction of mycobacterial growth can also be caused by their role in specific T helper 1 (Th1) and Th17 cell production (134). In contrast, it has been argued that neutrophils possess only poor direct antimycobacterial activity and that they instead facilitate the progression of infection (82). Silica particles are known to harm neutrophils in similar ways to that of their effect on macrophages, by decreasing their viability and phagocytic properties $(78,79)$.

\section{Other Cells [Basophils, Eosinophils, Natural Killer (NK) Cells]}

Detailed information about other components of the innate immune system in patients with silica-related TB is almost non-existent. A protective role for NK cells has been observed in mouse lung and splenic cultures infected with Mtb. In this study, production of IFN $\gamma$ by NK cells significantly contributed to limiting mycobacterial infection, independently of IFN $\gamma$ produced by $\mathrm{T}$ cells. Higher mycobacterial burden and granulocytic activity have been observed after depletion of Interleukin 12 (IL-12), which generally promotes NK cell cytotoxic activity (86). A decrease in NK cell number has been observed after the introduction of silica particles $(83,84)$. Detailed understanding of silica effects on NK cells is still lacking, but it has been observed that silica particles inhibit Toxoplasmainduced NK cell activity (135). By contrast, silica nanoparticles induce a significant increase in NK cells in mouse spleen, which may indicate a size-dependent effect of the particles on NK cells (85). 


\section{ADAPTIVE CELLULAR IMMUNE RESPONSES IN SILICOSIS AND TUBERCULOSIS}

\section{Antigen Presentation}

Antigen presentation is generally described as the presentation of lysed proteins on the surface of antigen-presenting cells (APCs) via the Major Histocompatibility Complexes (MHC), which is recognized by $\mathrm{T}$ cell receptors leading to their activation. Mycobacterial phospholipids activate CD1-mediated T cells (88, 89), and it has been observed that Mtb provides signaling for both T cells (lipid antigens) and APCs (polar lipids via TLR-2) (90).

Silica, as a pro-inflammatory agent, causes primarily induction of apoptosis of AMs. Various studies indicate that silica does not act as an antigen (136). Rather, silica particles support the increase of antigen-presenting properties of macrophages (87). Enhanced activation of AMs could also be related to autoimmune disease as a result of silica exposure. No significant differences were detected in the expression of $\mathrm{MHC}$ II molecules on AMs between silicosis and other diseases, such as sarcoidosis and allergic alveolitis (137). However, Pfau et al. (138) observed that silica-related antigens presented by apoptotic AMs are recognized by autoantibodies in mice. The question of how silica particles modulate presentation of antigen in the relationship with mycobacterial infection remains unanswered.

\section{T Lymphocytes-CD4+, CD8+, $\gamma \delta$ T Cells}

$\mathrm{T}$ cells activation occurs on exposure to an antigen which is presented by APCs. The major APCs responsible for defense against mycobacterial infection and activators of adaptive immunity are macrophages and dendritic cells. Broad antimycobacterial activity is provided by different subsets of $\mathrm{T}$ cells targeting a wide range of specific mycobacterial antigens. It is known, for example, that CD4+, CD8+, $\gamma \delta \mathrm{T}$ cells, and $\mathrm{CD} 1$ restricted $\mathrm{T}$ cells response to infection, contributing to bacteriostatic and bactericidal effects (77). CD4+ and CD8+ $\mathrm{T}$ cells act as IFN $\gamma$ producers and facilitate the phagocytic properties of macrophages (Figure 1). The activity of these subsets might be independent of each other, although their combined activity shows the strongest anti-mycobacterial effects (139). The onset of adaptive immunity is initiated with a significant delay after initial exposure to the pathogen. The restrictive activity of $\mathrm{T}$ cells is sufficient for bacterial arrest but not sufficient to kill mycobacteria, which might contribute to prolonged incubation and consequent re-activation of disease (140). In case of $\mathrm{T}$ cells response, a number of studies have confirmed that mycobacterial infection triggers Th2 response and $\mathrm{T}$ regulatory cells (Tregs) production rather than Th1 response. Deficiency in Th1 response may contribute to poor elimination and successful proliferation of Mtb in the host $(99,100)$.

The response of adaptive immunity components to silica particles is related to the cascade of activities mediated by the interaction with cells involved in innate immunity, particularly macrophages. However, direct interaction of $\mathrm{T}$ cells with silica cannot be excluded. It has been observed, that $\mathrm{T}$ cells acquire higher expression of FAS receptor and its ligands in lymphocytes obtained from bronchoalveolar lavage (BAL) fluid from silicaexposed individuals. This includes an over $20 \%$ increase in Fas receptor and more than $30 \%$ in Fas ligand on CD4+, CD8+ CD56+, and CD45RO+ cells, corresponding to the higher rate of apoptosis (30\%) (91). Both inflammatory and anti-inflammatory responses have been induced after exposure to silica. However, conflicting results in specific cytokine production have been reported, suggesting that there is a shift between Th1/Th2 responses during disease progression. There is noticeable inconsistency for another cytokine involved in Th1 response, IFN- $\gamma$. Its levels in lungs and lymph nodes have been reported as both elevated and undetected in silica-exposed mice. As a result of Th2 response, an increase in production of IL-12 mRNA and $\mathrm{IgG}_{1}$ has been reported in silicotic mice and in vitro $(92,96)$.

More recently, attention has been paid to the role of silica in autoimmune responses, in which autoimmune cells are activated by signals from silica-induced apoptotic macrophages (141). Following silica exposure, Tregs and Responder T cells (Tresps) are chronically activated and infiltrate the peripheral $\mathrm{T}$ cell population. By increased production of Fas ligand, Treg cells induce apoptosis and impair the immune response (97). Therefore, the overall number and inhibitory activity of $\mathrm{T}$ cells are reduced, with Tresps surviving due to an expression of apoptosis inhibitors (98). A closer look at cellular quantitative evaluation shows a silica-induced reduction of a number of macrophages and a consequential decrease of macrophagedependent activity of T- and NK cells (142).

Some of the features related to the leukocyte response modulation after silica exposure entail inconsistent and contradictory mechanistic effects regarding silica-TB cooccurrence. For example, increased production of TGF- $\beta$ as a reaction to silica (143) should assist in the process of elimination of Mtb, not its potentiation $(144,145)$. There is other evidence for a protective effect of silica in its interaction with the immune system, for example in protecting against the development of diabetes $(146,147)$.

\section{Antibody-Mediated Immunity}

B lymphocytes mediate specific immunological responses against pathogens via the production of specific antibodies. They can modulate responses to infection independent of antibodies; however, the mechanism(s) of such activity is not yet understood (148). The proliferation of plasma cells in patients with silicosis was discovered early $(149,150)$. Silica particles can cause both an increase and inhibition of $\mathrm{B}$ cell activity. Reduced and increased numbers of antibodies have been observed after exposure to silica in animal models. Moseley et al. (101) observed complete inhibition of immunoglobulin-secreting cells (ISCs) after the addition of silica in low- and high-density cultures depleted of monocytes. In contrast, in high-density cultures of unfractionated mononuclear cells, silica caused a significant increase in ISCs. It, therefore, seems that the number of immunoglobulin secreting cells is dependent not just on silica particles but also on other factors such as density of culture and presence of monocytes. A significant reduction in $\mathrm{B}$ cells was observed in mouse spleens treated 


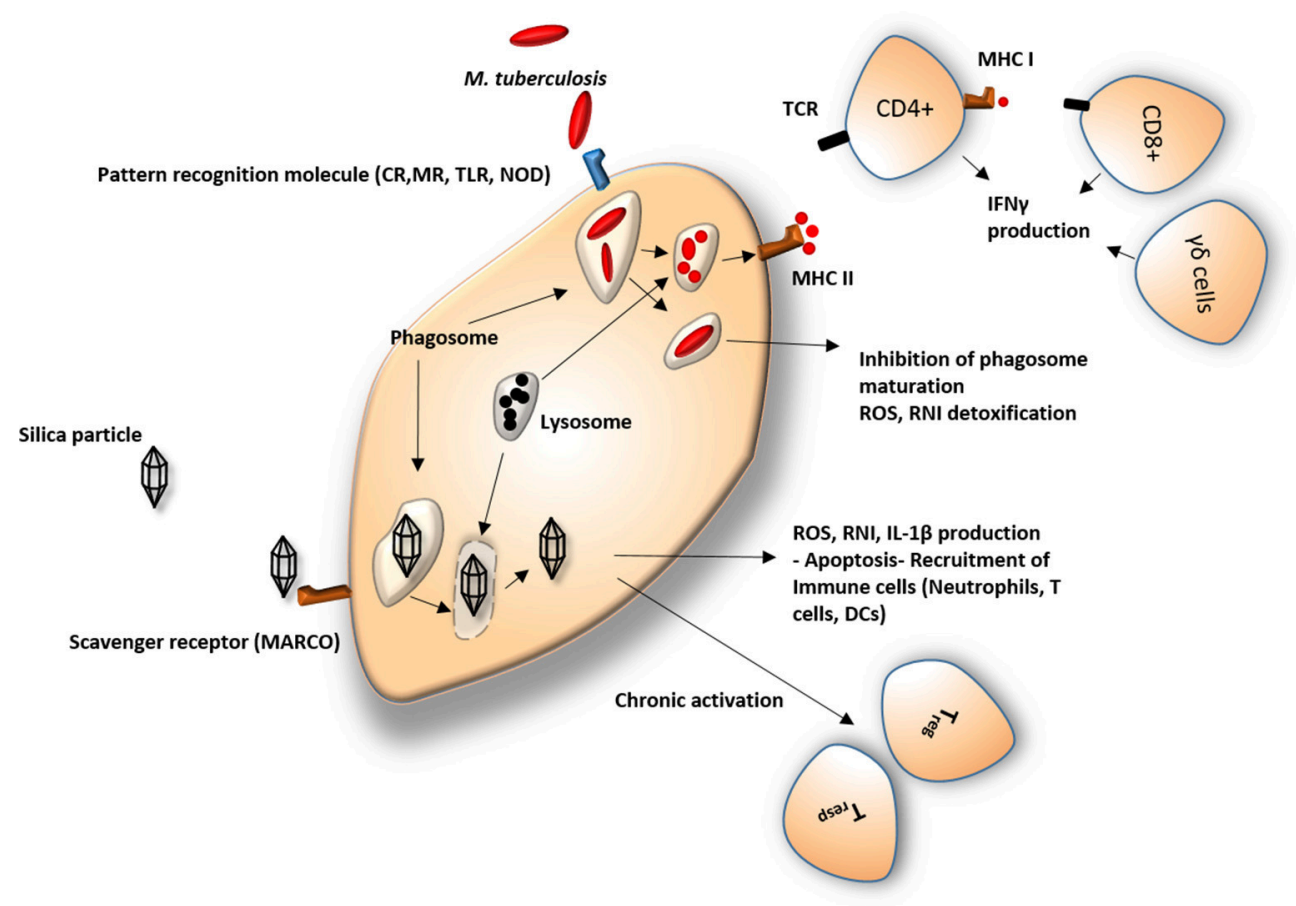

FIGURE 1 | Response of macrophage to silica and Mycobacterium. CR, Complement receptors; MR, Mannose receptors; TLR, Toll like receptors; NOD, Nod-like receptors; ROS, Reactive oxygen species; RNI, Reactive nitrogen intermediates; IL-1 $\beta$, Interleukin 1 beta; MHC I, major histocompatibility complex 1; MHC II, major histocompatibility complex 2; IFN $\gamma$, Interferon gamma; TCR, T-cell receptor; DCs, dendritic cells; CD4+/CD8+, effector T cells; Tregs, regulatory T cells; Tresps, responder T cells; $\gamma \delta$ cells, gamma delta T cells. Silica particles are usually recognized by scavenger receptors and engulfed by macrophages. Owing to the poor capability of the cell in eliminating the particle by standard lysosomal proteolytic enzymes, silica particles remain in the cell and initiate a cascade of pro- and anti-inflammatory processes, leading to a number of pathological modifications in the immune response. Mycobacterium is identified by a different set of cellular receptors but undergoes a similar process upon its ingestion. The physiological response of the immune system consists of digestion of bacilli and its antigen presentation on the cell surface leading to recruitment of effector cells such as CD4+ and CD8+ T cells. Mycobacterial evasive mechanisms frequently manage to avoid elimination, leading to pathological.

with silica nanoparticles (85). The most common effect of silica was an increase of autoantibodies such as rheumatoid factor (anti IgG), and anti-nuclear antibodies related to autoimmune diseases such as Caplan's syndrome, scleroderma, (ANCA)related vasculitis/nephritis, and systemic lupus erythematosus (97).

In response to mycobacterial infection, B cells do not simply act as producers of antibodies but also as modulators of $\mathrm{T}$ cell activity and development of $\mathrm{T}$ cell memory. They also influence the function of other effector cells such as DCs. The importance of B cells during mycobacterial infection is based on the co-operation and co-stimulation with other components of the immune system, suggesting more complex involvement in the immunological response (102). Antibodies in lymphocyte supernatants have been studied to obtain information about its diagnostic potential in pediatric TB patients. The findings indicated that antibodies were present at higher concentrations only during acute disease in $\mathrm{TB}$ positive patients compared to controls (151). Proliferating B cells are mostly present in sites of granulomas actively secreting TB-specific antibodies $(103,152)$ observed that abnormally located B cells in patients with TB are associated with a containment of Mtb and with IL-17 and IL22 production. The same group also described inhibitory effect of TB-related B cells on Th17 cell activation and therefore its involvement in CD4+ $\mathrm{T}$ cell regulation (104). While the overall role of $\mathrm{B}$ cells in the immune response to $M$. tuberculosis has been studied extensively $(153,154)$, its relationship with silica exposure has not yet been documented.

\section{CONCLUSION}

It is evident that the human immune system plays a central role in pathophysiological processes initiated after silica exposure and which have an impact on the development of TB. A detailed description of silica's involvement in TB infection, course, progression, re-activation and outcome has yet to be properly described. Existing research confirms the substantial role of the innate immune system in both direct defense and in the mobilization of other components of the immune system as a response to TB infection. Such findings are likely to underlie the higher susceptibility of silica-exposed and silicotic individuals to TB. However, there remain a number of gaps in knowledge, as summarized in Table $\mathbf{1 .}$

Recent findings suggest a more complex involvement of adaptive immunity in the containment and elimination of Mtb 
and its activation in latent infection. The effects of the immune response to silica exposure are complex and do not always lead to increased susceptibility to TB; some promote the elimination of mycobacteria rather than their proliferation. For example, silica-induced Th1 response activation, mediating $\mathrm{TNF} \alpha$ and IFN $\gamma$ production, should in theory contribute to resistance to or elimination of $\mathrm{Mtb}$. An increase in Th2 response after exposure to silica might be one of the contributing factors for successful propagation of Mtb. Discrepancies in evidence of pro- and anti-inflammatory pathway involvement, however, suggest more intricate reactions promoting fibrogenesis which might make a direct contribution to predisposition to TB.

The subject of this review has clinical relevance. The pathological activity of silica is important in the susceptibility to and prognosis of associated TB in silica-exposed populations globally. The considerations in this review should inform studies that aim to investigate outcomes of standard TB treatment regimens as they apply to silicotuberculosis by providing insight into mechanisms relevant to drug efficacy.

\section{REFERENCES}

1. Allison AC, Harington JS, Birbeck M. An examination of the cytotoxic effects of silica on macrophages. J Exp Med. (1966) 124:141-54. doi: $10.1084 /$ jem.124.2.141

2. Gulumian M, Borm PJ, Vallyathan V, Castranova V, Donaldson K, Nelson $\mathrm{G}$, et al. Mechanistically identified suitable biomarkers of exposure, effect, and susceptibility for silicosis and coal-worker's pneumoconiosis: a comprehensive review. J Toxicol Environ Health B Crit Rev. (2006) 9:357-95. doi: 10.1080/15287390500196537

3. Chavez-Galan L, Ramon-Luing LA, Torre-Bouscoulet L, Perez-Padilla R, Sada-Ovalle I. Pre-exposure of Mycobacterium tuberculosis-infected macrophages to crystalline silica impairs control of bacterial growth by deregulating the balance between apoptosis and necrosis. PLoS ONE (2013) 8:e80971. doi: 10.1371/journal.pone.0080971

4. Balmes JR. Commentary from JOEM forum- silicosis: then and now. J Occup Environ Med. (2017) 59:222-233. doi: 10.1097/JOM.00000000000009

5. Ding M, Chen F, Shi X, Yucesoy B, Mossman B, Vallyathan V. Diseases caused by silica: mechanisms of injury and disease development. Int Immunopharmacol. (2002) 2:173-82. doi: 10.1016/S1567-5769(01)00170-9

6. Leung CC, Yu IT, Chen W. Silicosis. Lancet (2012) 379:2008-18. doi: 10.1016/S0140-6736(12)60235-9

7. Cocco P, Rice CH, Chen JQ, McCawley MA, McLaughlin JK, Dosemeci M. Lung cancer risk, silica exposure, and silicosis in Chinese mines and pottery factories: the modifying role of other workplace lung carcinogens. Am J Ind Med. (2001) 40:674-82. doi: 10.1002/ajim.10022

8. Rimal B, Greenberg AK, Rom WN. Basic pathogenetic mechanisms in silicosis: current understanding. Curr Opin Pulm Med. (2005) 11:169-73. doi: 10.1097/01.mcp.0000152998.11335.24

9. Greenberg MI, Waksman J, Curtis J. Silicosis: a review. Dis Mon. (2007) 53:394-416. doi: 10.1016/j.disamonth.2007.09.020

10. Collis EL. Recent views on pneumonoconioses. Proc R Soc Med. (1931) 24:531-42.

11. Eide J, Gylseth B, Skaug V. Silicotic lesions of the bone marrow: histopathology and microanalysis. Histopathology (1984) 8:693-703. doi: 10.1111/j.1365-2559.1984.tb02381.x

12. Chen W, Zhuang Z, Attfield MD, Chen BT, Gao P, Harrison JC, et al. Exposure to silica and silicosis among tin miners in China: exposureresponse analyses and risk assessment. Occup Environ Med. (2001) 58:31-7. doi: 10.1136/oem.58.1.31

13. Deng H, Xu H, Zhang X, Sun Y, Wang R, Brann D, et al. Protective effect of Ac-SDKP on alveolar epithelial cells through inhibition of EMT
Finally, knowledge gained from the study of the silicaTB interaction could provide information relevant to the understanding of other pathological processes associated with silica exposure.

\section{AUTHOR CONTRIBUTIONS}

The subject of the review was co-conceived by all the authors. PK conducted the literature search and drafted the manuscript. RE, MG, and MJ contributed substantial intellectual content to the contents of the review and its finalization. All authors take responsibility for the final manuscript.

\section{FUNDING}

PK is funded by a Postdoctoral Fellowship awarded by the University Research Committee of the University of Cape Town.

via TGF-beta1/ROCK1 pathway in silicosis in rat. Toxicol Appl Pharmacol. (2016) 294:1-10. doi: 10.1016/j.taap.2016.01.010

14. Stanton DW, Belle BK, Dekker KJJ, Du Plessis JJL. South African Mining Industry Best Practice on the Prevention of Silicosis. Mine Health and Safety Council (2006). Available online at: http://www.oit.org/wcmsp5/groups/ public/---ed_protect/---protrav/---safework/documents/publication/ wcms_118101.pdf

15. Nelson G, Girdler-Brown B, Ndlovu N, Murray J. Three decades of silicosis: disease trends at autopsy in South African gold miners. Environ Health Perspect. (2010) 118:421-6. doi: 10.1289/ehp.0900918

16. Mendez-Vargas MM, Baez-Revueltas FB, Lopez-Rojas P, Tovalin-Ahumada JH, Zamudio-Lara JO, Marin-Cotonieto IA, et al. [Silicosis and industrial bronchitis by exposure to silica powders and cement]. Rev Med Inst Mex Seguro Soc. (2013) 51:384-9.

17. Antao VC, Pinheiro GA, Kavakama J, Terra-Filho M. High prevalence of silicosis among stone carvers in Brazil. Am J Ind Med. (2004) 45:194-201. doi: 10.1002/ajim.10331

18. Jindal SK. Silicosis in India: past and present. Curr Opin Pulm Med. (2013) 19:163-8. doi: 10.1097/MCP.0b013e32835bb19e

19. Nasrullah M, Mazurek JM, Wood JM, Bang KM, Kreiss K. Silicosis mortality with respiratory tuberculosis in the United States, 1968-2006. Am J Epidemiol. (2011) 174:839-48. doi: 10.1093/aje/kwr159

20. Zosky GR, Hoy RF, Silverstone EJ, Brims FJ, Miles S, Johnson AR, et al. Coal workers' pneumoconiosis: an Australian perspective. Med J Aust. (2016) 204:414-8. doi: 10.5694/mja16.00357

21. Gibson GJ, Loddenkemper R, Lundback B, Sibille Y. Respiratory health and disease in Europe: the new European Lung White Book. Eur Respir J. (2013) 42:559-63. doi: 10.1183/09031936.00105513

22. Hamilton RF Jr, Thakur SA, Mayfair JK, Holian A. MARCO mediates silica uptake and toxicity in alveolar macrophages from C57BL/6 mice. J Biol Chem. (2006) 281:34218-26. doi: 10.1074/jbc.M605229200

23. Beamer GL, Seaver BP, Jessop F, Shepherd DM, Beamer CA. Acute exposure to crystalline silica reduces macrophage activation in response to bacterial lipoproteins. Front Immunol (2016) 7:49. doi: 10.3389/fimmu.2016.00049

24. Shkurupy VA, Nadeev AP, Karpov MA, Bugrimova YS. Experimental cytomorphological studies of the reaction of mononuclear phagocyte system in granulomatosis of mixed (silicotic and tuberculous) etiology. Bull Exp Biol Med. (2010) 149:462-5. doi: 10.1007/s10517-010-0971-7

25. Fenoglio I, Croce A, Di Renzo F, Tiozzo R, Fubini B. Pure-silica zeolites (Porosils) as model solids for the evaluation of the physicochemical features determining silica toxicity to macrophages. Chem Res Toxicol. (2000) 13:489500. doi: 10.1021/tx990169u 
26. Denny JJ, Robson WD, Irwin DA. The prevention of silicosis by metallic aluminum: I. A preliminary report. Can Med Assoc J. (1937) 37:1-11.

27. Nash T, Allison AC, Harington JS. Physico-chemical properties of silica in relation to its toxicity. Nature (1966) 210:259-61. doi: 10.1038/210259a0

28. Stöber W, Brieger H. On the theory of silicosis. IV. The topochemical interaction. Arch Environ Health (1968) 16:706-8.

29. Huggins CW, Meyers GT. Report of Investigations 9053 Particle Size Distribution of Quartz and Other Respirable Dust Particles Collected at Metal Mines, Nonmetal Mines, and Processing Plants. US Department of the Interior. Bureau of Mines Report of Investigations (1986). Available online at: https://stacks.cdc.gov/view/cdc/10618

30. Hlavay J, Polyák K, Wesemann G. Particle size distribution of mineral phases and metals in dusts collected at different workplaces. Fresenius' J Analyt Chem. (1992) 344:319-21.

31. Lin W, Huang YW, Zhou XD, Ma Y. In vitro toxicity of silica nanoparticles in human lung cancer cells. Toxicol Appl Pharmacol. (2006) 217:252-9. doi: 10.1016/j.taap.2006.10.004

32. Fubini B, Ghiazza M, Fenoglio I. Physico-chemical features of engineered nanoparticles relevant to their toxicity. Nanotoxicology (2010) 4:347-63. doi: 10.3109/17435390.2010.509519

33. Wang Z, Wang C, Liu S, He W, Wang L, Gan J, et al. Specifically formed corona on silica nanoparticles enhances transforming growth factor betal activity in triggering lung fibrosis. ACS Nano (2017) 11:1659-72. doi: 10.1021/acsnano.6b07461

34. Ghio AJ, Kennedy TP, Schapira RM, Crumbliss AL, Hoidal JR. Hypothesis: is lung disease after silicate inhalation caused by oxidant generation? Lancet (1990) 336:967-9. doi: 10.1016/0140-6736(90)92 421-D

35. Borm PJ. Toxicity and occupational health hazards of coal fly ash (CFA). A review of data and comparison to coal mine dust. Ann Occup Hyg. (1997) 41:659-76. doi: 10.1016/S0003-4878(97)00026-4

36. Flynn JL, Chan J. Immunology of tuberculosis. Annu Rev Immunol. (2001) 19:93-129. doi: 10.1146/annurev.immunol.19.1.93

37. Fubini B, Hubbard A. Reactive oxygen species (ROS) and reactive nitrogen species (RNS) generation by silica in inflammation and fibrosis. Free Radic Biol Med. (2003) 34:1507-16. doi: 10.1016/S0891-5849(03)00149-7

38. Brown JM, Swindle EJ, Kushnir-Sukhov NM, Holian A, Metcalfe DD. Silicadirected mast cell activation is enhanced by scavenger receptors. Am J Respir Cell Mol Biol. (2007) 36:43-52. doi: 10.1165/rcmb.2006-0197OC

39. Nagelschmidt G. The relation between lung dust and lung pathology in pneumoconiosis. Br J Ind Med. (1960) 17:247-59. doi: 10.1136/oem.17.4.247

40. Castranova V, Vallyathan V. Silicosis and coal workers' pneumoconiosis. Environ Health Perspect. (2000) 108(Suppl. 4):675-84. doi: $10.1289 /$ ehp.00108s4675

41. Pavan C, Fubini B. Unveiling the variability of "quartz hazard" in light of recent toxicological findings. Chem Res Toxicol. (2017) 30:469-85. doi: 10.1021/acs.chemrestox.6b00409

42. WHO. Global Tuberculosis Report (2018).

43. Narasimhan P, Wood J, MacIntyre CR, Dilip M. Risk factors for tuberculosis. Pulmon Med. (2013) 2013:828939. doi: 10.1155/2013/828939

44. Lönnroth K, Williams BG, Stadlin S, Jaramillo E, Dye C. Alcohol use as a risk factor for tuberculosis - a systematic review. BMC Public Health (2008) 8:289. doi: 10.1186/1471-2458-8-289

45. Jeon CY, Murray MB. Diabetes mellitus increases the risk of active tuberculosis: a systematic review of 13 observational studies. PLoS Med. (2008) 5:e152. doi: 10.1371/journal.pmed.005015

46. Deiss RG, Rodwell TC, Garfein RS. Tuberculosis and illicit drug use: review and update. Clin Infect Dis. (2009) 48:72-82. doi: 10.1086/594126

47. Low A, Gavriilidis G, Larke N, B-Lajoie MR, Drouin O, Stover J, et al. Incidence of opportunistic infections and the impact of antiretroviral therapy among HIV-infected adults in low- and middle-income countries: a systematic review and meta-analysis. Clin Infect Dis. (2016) 62:1595-603. doi: $10.1093 / \mathrm{cid} / \mathrm{ciw} 125$

48. Khor CC, Chapman SJ, Vannberg FO, Dunne A, Murphy C, Ling EY, et al. A Mal functional variant is associated with protection against invasive pneumococcal disease, bacteremia, malaria and tuberculosis. Nat Genet. (2007) 39:523-8. doi: 10.1038/ng1976
49. Shweta SB, Bhatnagar S, Gupta AK, Murti K, Pandey K. Co-infection of visceral leishmaniasis and pulmonary tuberculosis: a case study. Asian Pac J Trop Dis. (2014) 4:57-60. doi: 10.1016/S2222-1808(14)60315-7

50. Bates MN, Khalakdina A, Pai M, Chang L, Lessa F, Smith KR. Risk of tuberculosis from exposure to tobacco smokea systematic review and meta-analysis. Arch Intern Med. (2007) 167:335-42. doi: 10.1001/archinte.167.4.335

51. Kurmi OP, Sadhra CS, Ayres JG, Sadhra SS. Tuberculosis risk from exposure to solid fuel smoke: a systematic review and meta-analysis. J Epidemiol Commun Health (2014) 68:1112-8. doi: 10.1136/jech-2014-204120

52. Öztürk $A B$, Kiliçaslan Z, Isssever $H$. Effect of smoking and indoor air pollution on the risk of tuberculosis: smoking, indoor air pollution and tuberculosis. Tuberk Toraks (2014) 62:1-6. doi: 10.5578/tt.7013

53. Cowie RL. The epidemiology of tuberculosis in gold miners with silicosis. Am J Respir Crit Care Med. (1994) 150(5 Pt 1):1460-2. doi: 10.1164/ajrccm.150.5.7952577

54. Barboza CE, Winter DH, Seiscento M, Santos Ude P, Terra Filho M. Tuberculosis and silicosis: epidemiology, diagnosis and chemoprophylaxis. J Bras Pneumol. (2008) 34:959-66. doi: 10.1590/S1806-37132008001100012

55. Gye WE, Kettle EH. Silicosis and Miners' phthisis. Br J Exp Pathol. (1922) 3:241-51.

56. Hnizdo E, Murray J, Sluis-Cremer GK, Thomas RG. Correlation between radiological and pathological diagnosis of silicosis: an autopsy population based study. Am J Ind Med. (1993) 24:427-45. doi: 10.1002/ajim.4700240408

57. Mossman BT, Churg A. Mechanisms in the pathogenesis of asbestosis and silicosis. Am J Respir Crit Care Med. (1998) 157(5 Pt 1):1666-80. doi: 10.1164/ajrccm.157.5.9707141

58. Sherson D. Silicosis in the twenty first century. Occup Environ Med. (2002) 59: 721-2. doi: 10.1136/oem.59.11.721

59. Churchyard GJ, Fielding KL, Grant AD. A trial of mass isoniazid preventive therapy for tuberculosis control. $N$ Engl J Med. (2014) 370:1662-3. doi: 10.1056/NEJMoa1214289

60. Parker J, Wagner GR. Silicosis. In: ILO Encyclopaedia of Occupational Health and Safety, Part I, Respiratory Disease. International Labour Organisation (2012).

61. Snider DE Jr. The relationship between tuberculosis and silicosis. Am Rev Respir Dis. (1978) 118:455-60.

62. Attygalle D, Harrison CV, King EJ, Mohanty GP. Infective pneumoconiosis. I. The influence of dead tubercle bacilli (BCG) on the dust lesions produced by anthracite, coal-mine dust, and kaolin in the lungs of rats and guinea-pigs. Br J Ind Med. (1954) 11:245-59.

63. Gernez-Rieux C, Tacquet A, Devulder B, Voisin C, Tonnel A, Aerts C, et al. Experimental study of interactions between pneumoconiosis and mycobacterial infections. Ann NY Acad Sci. (1972) 200:106-26.

64. Beamer CA, Holian A. Silica suppresses Toll-like receptor ligandinduced dendritic cell activation. FASEB J. (2008) 22:2053-63. doi: 10.1096/fj.07-095299

65. De Oliveira Abrão C, de Araújo Filho, JA. Mycobacterium sherrisii lung infection in a Brazilian patient with silicosis and a history of pulmonary tuberculosis. Case Rep Infect Dis. (2015) 2015:498608. doi: $10.1155 / 2015 / 498608$

66. Blanco Pérez JJ, Pérez González A, Morano Amado LE, Guerra Vales JL, Vázquez Gallardo R, Salgado Barreira Á, et al. Clinical significance of environmental mycobacteria isolated from respiratory specimens of patients with and without silicosis. Arch. Bronconeumol. (2016) 52:145-50. doi: 10.1016/j.arbres.2015.07.007

67. Qu Y, Tang Y, Cao D, Wu F, Liu J, Lu G, et al. Genetic polymorphisms in alveolar macrophage response-related genes, and risk of silicosis and pulmonary tuberculosis in Chinese iron miners. Int J Hyg Environ Health (2007) 210:679-89. doi: 10.1016/j.ijheh.2006.11.010

68. Corbett EL, Mozzato-Chamay N, Butterworth AE, De Cock KM, Williams BG, Churchyard GJ, et al. Polymorphisms in the tumor necrosis factor-alpha gene promoter may predispose to severe silicosis in black South African miners. Am J Respir Crit Care Med. (2002) 165:690-3. doi: $10.1164 /$ ajrccm.165.5.2010050

69. Wu F, Qu Y, Tang Y, Cao D, Sun P, Xia Z. Lack of association between cytokine gene polymorphisms and silicosis and pulmonary 
tuberculosis in Chinese iron miners. J Occup Health (2008) 50:445-54. doi: 10.1539/joh.L8006

70. Longhi G, Hanifi-Moghaddam P, Touabassy R, Saleh M. Macrophage infection by mycobacteria. Mycobact Dis. (2016) 6:1-11. doi: 10.4172/2161-1068.1000197

71. Ebina T, Takahashi Y, Hasuike T. Effect of quartz powder on tubercle bacilli and phagocytes. Am Rev Respir Dis. (1960) 82:516-27.

72. Dauber JH, Rossman MD, Daniele RP. Pulmonary fibrosis: bronchoalveolar cell types and impaired function of alveolar macrophages in experimental silicosis. Environ Res. (1982) 27:226-36. doi: 10.1016/0013-9351(82)90074-3

73. Pasula R, Britigan BE, Turner J, Martin WJ II. Airway delivery of silica increases susceptibility to mycobacterial infection in mice: potential role of repopulating macrophages. J Immunol. (2009) 182:7102-9. doi: 10.4049/jimmunol.0803642

74. Vallhov H, Gabrielsson S, Stromme M, Scheynius A, Garcia-Bennett AE. Mesoporous silica particles induce size dependent effects on human dendritic cells. Nano Lett. (2007) 7:3576-82. doi: 10.1021/nl0714785

75. Wolf AJ, Linas B, Trevejo-Nunez GJ, Kincaid E, Tamura T, Takatsu K, et al. Mycobacterium tuberculosis infects dendritic cells with high frequency and impairs their function in vivo. J Immunol. (2007) 179:2509-19. doi: 10.4049/jimmunol.179.4.2509

76. Henderson, RA, Watkins SC, Flynn JL. Activation of human dendritic cells following infection with Mycobacterium tuberculosis. J Immunol. (1997) 159:635-43.

77. Boom WH, Canaday DH, Fulton SA, Gehring AJ, Rojas RE, Torres M. Human immunity to M. tuberculosis: T cell subsets and antigen processing. Tuberculosis (Edinb) (2003) 83:98-106. doi: 10.1016/S1472-9792(02)00054-9

78. Zimmerman BT, Canono BP, Campbell PA. Silica decreases phagocytosis and bactericidal activity of both macrophages and neutrophils in vitro. Immunology (1986) 59:521-5.

79. Leigh J, Wang H, Bonin A, Peters M, Ruan X. Silica-induced apoptosis in alveolar and granulomatous cells in vivo. Environ Health Perspect. (1997) 105(Suppl. 5):1241-5.

80. Zay K, Loo S, Xie C, Devine DV, Wright J, Churg A. Role of neutrophils and alpha1-antitrypsin in coal- and silica-induced connective tissue breakdown. Am J Physiol. (1999) 276(2 Pt 1):L269-79.

81. Ramos-Kichik V, Mondragon-Flores R, Mondragon-Castelan M, GonzalezPozos S, Muniz-Hernandez S, Rojas-Espinosa O, et al. Neutrophil extracellular traps are induced by Mycobacterium tuberculosis. Tuberculosis (Edinb) (2009) 89:29-37. doi: 10.1016/j.tube.2008.09.009

82. Eruslanov EB, Lyadova IV, Kondratieva TK, Majorov KB, Scheglov IV, Orlova MO et al. Neutrophil responses to Mycobacterium tuberculosis infection in genetically susceptible and resistant mice. Infect Immun. (2005) 73:1744-53. doi: 10.1128/IAI.73.3.1744-1753.2005

83. Kiessling R, Hochman PS, Haller O, Shearer GM, Wigzell H, Cudkowicz G. Evidence for a similar or common mechanism for natural killer cell activity and resistance to hemopoietic grafts. Eur J Immunol. (1977) 7:655-63. doi: 10.1002/eji.1830070915

84. Riccardi C, Santoni A, Barlozzari T, Herberman RB. In vivo reactivity of mouse natural killer (NK) cells against normal bone marrow cells. Cell Immunol. (1981) 60:136-43. doi: 10.1016/0008-8749(81)90254-9

85. Park EJ, Park K. Oxidative stress and pro-inflammatory responses induced by silica nanoparticles in vivo and in vitro. Toxicol Lett. (2009) 184:18-25. doi: 10.1016/j.toxlet.2008.10.012

86. Feng CG, Kaviratne M, Rothfuchs AG, Cheever A, Hieny S, Young HA, et al. NK cell-derived IFN-gamma differentially regulates innate resistance and neutrophil response in $\mathrm{T}$ cell-deficient hosts infected with Mycobacterium tuberculosis. J Immunol. (2006) 177:7086-93. doi: 10.4049/jimmunol.177.10.7086

87. Migliaccio CT, Hamilton RF Jr, Holian A. Increase in a distinct pulmonary macrophage subset possessing an antigen-presenting cell phenotype and in vitro APC activity following silica exposure. Toxicol Appl Pharmacol. (2005) 205:168-76. doi: 10.1016/j.taap.2004.11.005

88. Matsunaga I, Bhatt A, Young DC, Cheng TY, Eyles SJ, Besra GS, et al. Mycobacterium tuberculosis pks12 produces a novel polyketide presented by CD1c to T cells. J Exp Med. (2004) 200:1559-69. doi: 10.1084/jem.20041429

89. Ulrichs T, Moody DB, Grant E, Kaufmann SH, Porcelli SA. Tcell responses to $\mathrm{CD} 1$-presented lipid antigens in humans with
Mycobacterium tuberculosis infection. Infect Immun. (2003) 71:3076-87. doi: 10.1128/IAI.71.6.3076-3087.2003

90. Roura-Mir C, Wang L, Cheng TY, Matsunaga I, Dascher CC, Peng SL, et al. Mycobacterium tuberculosis regulates CD1 antigen presentation pathways through TLR-2. J Immunol. (2005) 175:1758-66. doi: 10.4049/jimmunol.175.3.1758

91. Hamzaoui A, Ammar J, Grairi H, Hamzaoui K. Expression of Fas antigen and Fas ligand in bronchoalveolar lavage from silicosis patients. Mediators Inflamm. (2003) 12:209-14. doi: 10.1080/09629350310001599648

92. Huaux F, Lardot C, Arras M, Delos M, Many MC, Coutelier JP, et al. Lung fibrosis induced by silica particles in NMRI mice is associated with an upregulation of the p40 subunit of interleukin-12 and Th-2 manifestations. Am J Respir Cell Mol Biol. (1999) 20:561-72. doi: 10.1165/ajrcmb.20.4.3342

93. Garn H, Friedetzky A, Kirchner A, Jager R, Gemsa D. Experimental silicosis: a shift to a preferential IFN-gamma-based Th1 response in thoracic lymph nodes. Am J Physiol Lung Cell Mol Physiol. (2000) 278:L1221-30. doi: 10.1152/ajplung.2000.278.6.L1221

94. Davis GS, Pfeiffer LM, Hemenway DR. Interferon-gamma production by specific lung lymphocyte phenotypes in silicosis in mice. Am J Respir Cell Mol Biol. (2000) 22:491-501. doi: 10.1165/ajrcmb.22.4.3599

95. Barbarin V, Xing Z, Delos M, Lison D, Huaux F. Pulmonary overexpression of IL-10 augments lung fibrosis and Th2 responses induced by silica particles. Am J Physiol Lung Cell Mol Physiol. (2005) 288:L841-8. doi: 10.1152/ajplung.00329.2004

96. Huaux F. New developments in the understanding of immunology in silicosis. Curr Opin Allergy Clin Immunol. (2007) 7:168-73. doi: 10.1097/ACI.0b013e32802bf8a5

97. Lee S, Hayashi H, Maeda M, Matsuzaki H, Kumagai-Takei N, Chen $\mathrm{Y}$, et al. Chapter 9: Immunostimulation by silica particles and the development of autoimmune dysregulation. In: Immune Response Activation. Croatia: InTech Open Access Publisher (2014), 249-265. Available online at: https://www.intechopen.com/books/immune-responseactivation/immunostimulation-by-silica-particles-and-the-developmentof-autoimmune-dysregulation

98. Lee S, Hayashi H, Maeda M, Chen Y, Matsuzaki H, Kumagai-Takei N, et al. Environmental factors producing autoimmune dysregulation-chronic activation of $\mathrm{T}$ cells caused by silica exposure. Immunobiology (2012) 217:743-8. doi: 10.1016/j.imbio.2011.12.009

99. Lienhardt C, Azzurri A, Amedei A, Fielding K, Sillah J, Sow OY, et al. Active tuberculosis in Africa is associated with reduced Th1 and increased Th2 activity in vivo. Eur J Immunol. (2002) 32:1605-13. doi: 10.1002/1521-4141(200206)32:6<1605::AID-IMMU1605>3.0.CO;2-6

100. He XY, Xiao L, Chen HB, Hao J, Li J, Wang YJ, et al. T regulatory cells and Th1/Th2 cytokines in peripheral blood from tuberculosis patients. Eur J Clin Microbiol Infect Dis. (2010) 29:643-50. doi: 10.1007/s10096-0100908-0

101. Moseley PL, Monick M, Hunninghake GW. Divergent effects of silica on lymphocyte proliferation and immunoglobulin production. J Appl Physiol. (1988) 65:350-7. doi: 10.1152/jappl.1988.65.1.350

102. Kozakiewicz L, Phuah J, Flynn J, Chan J. The role of B cells and humoral immunity in Mycobacterium tuberculosis infection. In: Divangahi M, editor. The New Paradigm of Immunity to Tuberculosis. Advances in Experimental Medicine and Biology, Vol. 783. New York, NY: Springer (2013). p. 225-50. doi: 10.1007/978-1-4614-6111-1_12

103. Zhang M, Wang Z, Graner MW, Yang L, Liao M, Yang Q, et al. B cell infiltration is associated with the increased IL-17 and IL-22 expression in the lungs of patients with tuberculosis. Cell Immunol. (2011) 270:217-23. doi: 10.1016/j.cellimm.2011.05.009

104. Zhang $\mathrm{M}$, Zheng $\mathrm{X}$, Zhang J, Zhu $\mathrm{Y}$, Zhu $\mathrm{X}$, Liu $\mathrm{H}$, et al. $\mathrm{CD} 19(+) \mathrm{CD} 1 \mathrm{~d}(+) \mathrm{CD} 5(+)$ B cell frequencies are increased in patients with tuberculosis and suppress Th17 responses. Cell Immunol. (2012) 274:89-97. doi: 10.1016/j.cellimm.2012.01.007

105. Harington JS. Some biological actions of silica: their part in the pathogenesis of silicosis. S Afr Med J. (1963) 37:451-6.

106. Adamis Z, Timar M. Studies on the effect of quartz, bentonite and coal dust mixtures on macrophages in vitro. Br J Exp Pathol. (1978) 59:411-5.

107. Dubois CM, Bissonnette E, Rola-Pleszczynski M. Asbestos fibers and silica particles stimulate rat alveolar macrophages to release tumor necrosis factor. 
Autoregulatory role of leukotriene B4. Am Rev Respir Dis. (1989) 139:125764. doi: 10.1164/ajrccm/139.5.1257

108. Hamilton RF Jr, Thakur SA, Holian A. Silica binding and toxicity in alveolar macrophages. Free Radic Biol Med. (2008) 44:1246-58. doi: 10.1016/j.freeradbiomed.2007.12.027

109. Liang D, Wang Y, Zhu Z, Yang G, An G, Li X, et al. BMP7 attenuated silica-induced pulmonary fibrosis through modulation of the balance between TGF-beta/Smad and BMP-7/Smad signaling pathway. Chem Biol Interact. (2016) 243:72-81. doi: 10.1016/j.cbi.2015. 11.012

110. De Voss JJ, Rutter K, Schroeder BG, Su H, Zhu Y, Barry CE III. The salicylatederived mycobactin siderophores of Mycobacterium tuberculosis are essential for growth in macrophages. Proc Natl Acad Sci USA. (2000) 97:1252-7. doi: 10.1073/pnas.97.3.1252

111. Berrington WR, Hawn TR. Mycobacterium tuberculosis, macrophages, and the innate immune response: does common variation matter? Immunol Rev. (2007) 219:167-86. doi: 10.1111/j.1600-065X.2007.00545.x

112. Pieters J. Mycobacterium tuberculosis and the macrophage: maintaining a balance. Cell Host Microbe (2008) 3:399-407. doi: 10.1016/j.chom.2008.05.006

113. Guirado E, Schlesinger LS, Kaplan G. Macrophages in tuberculosis: friend or foe. Semin Immunopathol. (2013) 35:563-83. doi: $10.1007 / \mathrm{s} 00281-013-0388-2$

114. Podinovskaia M, Lee W, Caldwell S, Russell DG. Infection of macrophages with Mycobacterium tuberculosis induces global modifications to phagosomal function. Cell Microbiol. (2013) 15:843-59. doi: $10.1111 / \mathrm{cmi} .12092$

115. Neyrolles O, Wolschendorf F, Mitra A, Niederweis M. Mycobacteria, metals, and the macrophage. Immunol Rev. (2015) 264:249-63. doi: 10.1111/imr.12265

116. Mukhopadhyay S, Gal AA. Granulomatous lung disease: an approach to the differential diagnosis. Arch Pathol Lab Med. (2010) 134:667-90. doi: 10.1043/1543-2165-134.5.667

117. Huynh KK, Joshi SA, Brown EJ. A delicate dance: host response to mycobacteria. Curr Opin Immunol. (2011) 23:464-72. doi: 10.1016/j.coi.2011.06.002

118. Guirado E, Schlesinger LS. Modeling the Mycobacterium tuberculosis granuloma - the critical battlefield in host immunity and disease. Front Immunol. (2013) 4:98. doi: 10.3389/fimmu.2013.00098

119. Allison AC, Hart PD. Potentiation by silica of the growth of Mycobacterium tuberculosis in macrophage cultures. Br J Exp Pathol. (1968) 49:465-76.

120. Arkhipov SA, Shkurupy VA, Bugrimova YS. Effect of preliminary load of macrophages with silicium dioxide on phagocytosis of BCG strain micobacteria by macrophages and antimicrobial activity. Bull Exp Biol Med. (2010) 149:534-6. doi: 10.1007/s10517-010-0986-0

121. Gaynor CD, McCormack FX, Voelker DR, McGowan SE, Schlesinger LS. Pulmonary surfactant protein A mediates enhanced phagocytosis of Mycobacterium tuberculosis by a direct interaction with human macrophages. J Immunol. (1995) 155:5343-51.

122. Downing JF, Pasula R, Wright JR, Twigg HL III, Martin WJ II. Surfactant protein a promotes attachment of Mycobacterium tuberculosis to alveolar macrophages during infection with human immunodeficiency virus. Proc Natl Acad Sci USA. (1995) 92:4848-52.

123. Pasula R, Downing JF, Wright JR, Kachel DL, Davis TE Jr, Martin WJ II. Surfactant protein A (SP-A) mediates attachment of Mycobacterium tuberculosis to murine alveolar macrophages. Am J Respir Cell Mol Biol. (1997) 17:209-17.

124. Viviano CJ, Rooney SA. Early increase in expression of surfactant protein A gene in type II cells from silica-treated rats. Am J Physiol. (1997) 273(2 Pt 1):L395-400.

125. Spech RW, Wisniowski P, Kachel DL, Wright, JR, Martin WJ II. Surfactant protein A prevents silica-mediated toxicity to rat alveolar macrophages. Am J Physiol Lung Cell Mol Physiol. (2000) 278:L713-8. doi: 10.1152/ajplung.2000.278.4.L713

126. Beamer CA, Holian A. Antigen-presenting cell population dynamics during murine silicosis. Am J Respir Cell Mol Biol. (2007) 37:729-38. doi: $10.1165 / \mathrm{rcmb} .2007-0099 \mathrm{OC}$
127. Tailleux L, Schwartz O, Herrmann JL, Pivert E, Jackson M, Amara A, et al. DC-SIGN is the major Mycobacterium tuberculosis receptor on human dendritic cells. J Exp Med. (2003) 197:121-7. doi: 10.1084/jem.20021468

128. Giacomini E, Iona E, Ferroni L, Miettinen M, Fattorini L, Orefici $G$, et al. Infection of human macrophages and dendritic cells with Mycobacterium tuberculosis induces a differential cytokine gene expression that modulates $\mathrm{T}$ cell response. J Immunol. (2001) 166:7033-41. doi: 10.4049/jimmunol.166.12.7033

129. Eum SY, Kong JH, Hong MS, Lee YJ, Kim JH, Hwang SH, et al. Neutrophils are the predominant infected phagocytic cells in the airways of patients with active pulmonary TB. Chest (2010) 137:122-8. doi: 10.1378/chest.09-0903

130. Sugawara I, Udagawa $T$, Yamada $H$. Rat neutrophils prevent the development of tuberculosis. Infect Immun. (2004) 72:1804-6. doi: 10.1128/IAI.72.3.1804-1806.2004

131. Pedrosa J, Saunders BM, Appelberg R, Orme IM, Silva MT, Cooper AM. Neutrophils play a protective nonphagocytic role in systemic Mycobacterium tuberculosis infection of mice. Infect Immun. (2000) 68:57783. doi: 10.1128/IAI.68.2.577-583.2000

132. Martineau AR, Newton SM, Wilkinson KA, Kampmann B, Hall BM, Nawroly $\mathrm{N}$, et al. Neutrophil-mediated innate immune resistance to mycobacteria. $J$ Clin Invest. (2007) 117:1988-94. doi: 10.1172/JCI31097

133. Yang CT, Cambier CJ, Davis JM, Hall CJ, Crosier PS, Ramakrishnan L. Neutrophils exert protection in the early tuberculous granuloma by oxidative killing of mycobacteria phagocytosed from infected macrophages. Cell Host Microbe (2012) 12:301-12. doi: 10.1016/j.chom.2012.07.009

134. Trentini MM, de Oliveira FM, Kipnis A, Junqueira-Kipnis AP. The role of neutrophils in the induction of specific Th1 and Th17 during vaccination against tuberculosis. Front Microbiol. (2016) 7:1-13. doi: $10.3389 /$ fmicb. 2016.00898

135. Hauser WE Jr, Sharma SD, Remington JS. Natural killer cells induced by acute and chronic toxoplasma infection. Cell Immunol. (1982) 69:330-46. doi: 10.1016/0008-8749(82)90076-4

136. Weirich U, Friemann J, Rehn B, Henkeludecke U, Lammers T, Sorg C, et al. Silicotic lymph node reactions in mice: genetic differences, correlation with macrophage markers, and independence from T lymphocytes. J Leukoc Biol. (1996) 59:178-88. doi: 10.1002/jlb.59.2.178

137. Bretana A, Goihman-Yahr M, Tapia FJ, Isturiz G, Viloria N, Carrasquero M, et al. Comparative ultrastructure and immunolabeling of MHC-II antigens of alveolar macrophages obtained from patients with paracoccidioidomycosis and other lung diseases. J Leukoc Biol. (1995) 57:101-9.

138. Pfau JC, Brown JM, Holian A. Silica-exposed mice generate autoantibodies to apoptotic cells. Toxicology (2004) 195:167-76. doi: 10.1016/j.tox.2003.09.011

139. Tufariello JM, Chan J, Flynn JL. Latent tuberculosis: mechanisms of host and bacillus that contribute to persistent infection. Lancet Infect Dis. (2003) 3:578-90. doi: 10.1016/S1473-3099(03)00741-2

140. Ernst JD. The immunological life cycle of tuberculosis. Nat Rev Immunol. (2012) 12:581-91. doi: 10.1038/nri3259

141. Kumagai-Takei N, Hayashi H, Maeda M, Miura I, Matsuzaki H, Lee S, et al. Chapter 9: Immunological effects of silica and related dysregulation of autoimmunity. In: Mavragani CP, editor. Autoimmune DisordersPathogenetic Aspects. Immunological Effects of Silica and Related Altered Regulation of Autoimmunity. Croatia: InTech Open Access Publisher (2011), 157-174.

142. Amano K, Yoon JW. Studies on autoimmunity for initiation of beta-cell destruction. V. Decrease of macrophage-dependent $\mathrm{T}$ lymphocytes and natural killer cytotoxicity in silica-treated BB rats. Diabetes (1990) 39:590-6. doi: $10.2337 /$ diab.39.5.590

143. Jagirdar J, Begin R, Dufresne A, Goswami S, Lee TC, Rom WN. Transforming growth factor-beta (TGF-beta) in silicosis. Am J Respir Crit Care Med. (1996) 154(4 Pt 1):1076-81. doi: 10.1164/ajrccm.154.4.8887610

144. Champsi J, Young LS, Bermudez LE. Production of TNF-alpha, IL-6 and TGF-beta, and expression of receptors for TNF-alpha and IL-6, during murine Mycobacterium avium infection. Immunology (1995) 84:549-54.

145. Toossi Z, Gogate P, Shiratsuchi H, Young T, Ellner JJ. Enhanced production of TGF-beta by blood monocytes from patients with active tuberculosis and presence of TGF-beta in tuberculous granulomatous lung lesions. J Immunol. (1995) 154:465-73. 
146. Oschilewski U, Kiesel U, Kolb H. Administration of silica prevents diabetes in BB-rats. Diabetes (1985) 34:197-9. doi: 10.2337/diab.34.2.197

147. Charlton B, Bacelj A, Mandel TE. Administration of silica particles or anti-Lyt2 antibody prevents beta-cell destruction in NOD mice given cyclophosphamide. Diabetes (1988) 37:930-5. doi: 10.2337/diab.37.7.930

148. Maglione PJ, Chan J. How B cells shape the immune response against Mycobacterium tuberculosis. Eur J Immunol. (2009) 39:676-86. doi: $10.1002 /$ eji.200839148

149. Vigliani EC, Pernis B. Immunological factors in the pathogenesis of the hyaline tissue of silicosis. Ind Med Surg. (1958) 27:643-5. doi: $10.1136 /$ oem.15.1.8

150. Vigliani EC, Pernis B. An immunological approach to silicosis. J Occup Environ Med. (1959) 1:319-28.

151. Raqib R, Mondal D, Karim MA, Chowdhury F, Ahmed S, Luby S, et al. Detection of antibodies secreted from circulating Mycobacterium tuberculosis-specific plasma cells in the diagnosis of pediatric tuberculosis. Clin Vaccine Immunol. (2009) 16:521-7. doi: 10.1128/CVI.00391-08

152. Phuah JY, Mattila JT, Lin PL, Flynn JL. Activated B cells in the granulomas of nonhuman primates infected with Mycobacterium tuberculosis. Am J Pathol. (2012) 181:508-14. doi: 10.1016/j.ajpath.2012.05.009
153. Chan J, Mehta S, Bharrhan S, Chen Y, Achkar JM, Casadevall A, et al. The role of B cells and humoral immunity in Mycobacterium tuberculosis infection. Semin Immunol. (2014) 26:588-600. doi: 10.1016/j.smim.2014. 10.005

154. Rao M, Valentini D, Poiret T, Dodoo E, Parida S, Zumla A, et al. B in TB: B cells as mediators of clinically relevant immune responses in Tuberculosis. Clin Infect Dis. (2015) 61(Suppl. 3):S225-34. doi: 10.1093/cid/ civ614

Conflict of Interest Statement: The authors declare that the research was conducted in the absence of any commercial or financial relationships that could be construed as a potential conflict of interest.

Copyright (๑ 2019 Konečný, Ehrlich, Gulumian and Jacobs. This is an open-access article distributed under the terms of the Creative Commons Attribution License (CC $B Y)$. The use, distribution or reproduction in other forums is permitted, provided the original author(s) and the copyright owner(s) are credited and that the original publication in this journal is cited, in accordance with accepted academic practice. No use, distribution or reproduction is permitted which does not comply with these terms. 